\title{
Strengthening in-Local Wisdom Disaster Risk Reduction on Mount Slamet
}

\author{
Agus Setio Widodo ${ }^{1}$, Dwian Hartomi Akta Padma Eldo ${ }^{2}$ \\ Pancasakti University Tegal, Jl Halmahera KM 1, Tegal City ${ }^{1,2}$ \\ \{lecturer_muda@yahoo.co.id ${ }^{1}$, dwian hartomieldo@upstegal.ac.id $\left.{ }^{2}\right\}$
}

\begin{abstract}
This study aims to see how the role of local wisdom in reducing the risk of Mount Slamet disaster. Besides the research is also going to discuss about the factors that hinder the wisdom of the local in the reduction of the risk of disaster in Mount Slamet. The method used is qualitative with data collection techniques using interviews, literature study and observation. The research results found that: 1). The role of local wisdom which is manifested and represented by the caretaker is still quite low formally. 2) Factors that hinder the role of local wisdom in disaster risk reduction are the carrying capacity of regulations which do not leave room for key officers. The conclusions of the research are: 1) Formally the role of caretaker as the embodiment of local wisdom is still low, but informally it is acknowledged by the community. 2). The factor that affects / hinders the role of local wisdom is regulation, namely Law Number 24 of 2007 which does not reinforce the role of the mountain caretaker as local wisdom. The resulting recommendation is the need for recognition of the role of local wisdom by Mount Slamet's spokesmen in disaster risk reduction, both formally and informally.
\end{abstract}

Keywords: Local Wisdom, Disaster Risk, Mount Slamet

\section{Introduction}

We cannot detect when a disaster occurs, where and how big the escalation or impact is. At the same time, Law Number 24 of 2007 concerning disaster management mandates the mainstreaming of local values in disaster management. In fact, disaster risk reduction is not only the task of the government, but requires the joint role of all elements (government, private sector, community and the international community). The reality on the ground is that we are often unprepared, even underestimating the arrival of a disaster. There is no good partnership / network, especially between formal actors and informal actors.

Society has been still think that matters are the responsibility of the government disaster. This means that people's attitudes tend to be passive. Meanwhile, on the other hand, the presence of an informal community leader, namely the caretaker of the mountain, is still more obeyed by the community. Phenomena in the field indicate that the existing network is still very weak. Relationships between actors and stakeholders in disaster risk reduction, both official (bureaucratic) and informal (public and private) tend to be independent and sporadic. The tendency is to act independently so that there is no role sharing, structure, let alone 
standard operating procedures (SOP) in reducing the risk of the Mount Slamet disaster, except for bureaucratic actors or institutions.

On the other hand, in the view of the community, Mount Slamet, according to its name, is considered to have a " slamet" character, which means that it will always provide a sense of security and prosper the community. The mountain that was once named Mount Agung has a very important function as a buffer and regulator of the water system. In addition, the Mount Slamet area is also a place of livelihood for the Forest Village community and a place for flora and fauna to live. Effective network management is needed because disaster management is not only the responsibility of the government but also the public and the private sector. This is the starting point for placing the role of local wisdom in contributing to disaster risk reduction. The phenomena that can be captured from field conditions are:

a. The large number of caretakers for Mount Slamet, there are at least 8 caretakers on each hiking trail

b. The community still appreciates the existence of a caretaker by making him a spiritual figure for the benefit of mountain climbing

c. There are different views on the importance of not evacuating every time there is an increase in mountain status.

Based on the existing phenomena, several problems were identified as follows:

1. Low local wisdom in disaster risk reduction of Mount Slamet, where at all stages of disaster management is always dominated by the consideration of disaster technical assumptions without sufficient space for the value of local wisdom.

2. There is a potential for conflict between the jurukunci and the government in an effort to reduce the risk of the Mount Slamet disaster

3. The low level of political support for the development of local wisdom in disaster management efforts, where none of the regional heads listed local wisdom in disaster management as one of their program priorities. (source: www.purbalinggakab.go.id)

In accordance with the existing phenomenon and problem identification, the formulation of the research problem is as follows: (1) What is the role of the caretaker as local wisdom in reducing the risk of the Mount Slamet disaster? ; (2) What factors hinder the strengthening of the role of local wisdom in reducing the risk of Mount Slamet?

The novelty that is expected to emerge from this research is the development of a model for strengthening local wisdom in reducing the risk of Mount Slamet. It is hoped that this can strengthen community participation in disaster risk reduction so that it can reduce the possibility of casualties and other losses due to the eruption of Mount Slamet. This hope can at the same time fill the research gap which has been more reactive (post disaster) towards an anticipatory (proactive) direction before a disaster occurs. It is hoped that this research will be useful to enrich the treasury of government science, particularly in the field of disaster management. The results of this study are expected to provide practical contributions in the form of a disaster risk reduction model in Tegal, Pemalang, Brebes, Purbalingga and Banyumas Regencies, Central Java Province.

\section{Literature Review}

The governance paradigm provides the prospect that the people will be able to be more proactive in government administration activities. If the government paradigm looks at the formal hierarchical structure of government, the governance paradigm looks at the dynamics of politics and government in a broad and horizontal arena (Sorensen, 2002 in Lay and 
Masudi, 2005: 227). This means that state monopolies are no longer suitable for solving complex, dynamic and diverse problems. In the context of disaster management the basic question that is then asked is who should carry out disaster management? Who should be responsible for any existing disaster management processes? Who should prevent, give warnings, act in an emergency response situation?

Understanding of disaster management as a shared problem ( common problem ) need a map $\mathrm{p}$ ing structure interaction and involvement of various parties in direct contact with the causes and victims of disasters. The parties in question include elements of the government and non-government actors, both private, $\mathrm{NGO} / \mathrm{NGO}$, and community. Of course, the various roles and responsibilities will be different. However, that an integrated disaster management system requires a synergistic interaction of all these actors is a necessity. It is in these circumstances that the value of local wisdom is present as a representation of community involvement in disaster management. Local wisdom that is personified from the figure of the caretaker of Mount Slamet is considered to represent the belief system of the local community that Mount Slamet will remain safe because it is protected by invisible figures who are legendary in people's beliefs.

The existence of a potential conflict between local wisdom versus public policy is a necessity. As stated by Lewis A. Coser (1956) in the book The function of Social conflict, explains the notion of conflict as a struggle for values or demands for status. Coser has the view that conflict in society is a normal event that can strengthen the structure of social relationships. The absence of conflict in a society can not be regarded as an indication of the strength and stability of the social relations of the community. The development of conflict in society is not the main and single indicator to say that the social stability of that society has been achieved . Conflict in view Coser is a struggle over values and demand status pace, power, and resources that neutralize the purposes opponent to injure or eliminate opponents brand a.

As the essence of the theory building process, a concept definition for this study was prepared. The definition of a concept is an abstraction expressed in words that can help understand the concepts to be studied as stated in the objectives / research phenomenon. For this reason, the authors propose the following concept definition:

a. The role of local wisdom is a work carried out and carried out by people who are according to their status as caretakers of the mountain in the context of Mount Slamet disaster risk reduction (PRB).

b. Disaster risk reduction is a systematic effort both structurally (policy) and non-structural (physical) in reducing the adverse effects of disasters.

Concept operationalization based on conceptional definitions is directed according to the phenomena seen in the field. Phenomenon (phainomenon) is defined as what is seen which can be facts, symptoms or what is felt by the five senses. Phenomena are events that are neutral in nature. It can be said that the phenomenon is a symptom ( symptoms) or the fact that indicates there is his problem that needs to be investigated.

\section{Research Methods}

This study uses a qualitative research approach. The study qualitative intended to understand the problems of human and social are very complex, for medeskripsikan overview of the thorough and complete and detail that comes from informants in circumstances that naturally what their . Type of research qualitative were taken in the study of this is the study 
of the case . Yin (2004) identifies the steps a case study researcher should take: 1). Arranging research questions, 2) Developing propositions, 3) Establishing units of analysis, 4) Linking logically between data and propositions, 5) Establishing data interpretation criteria.

Studies of cases used to be able to express an object of research specified that Memi li ki specificity or uniqueness that is called the " case ". This method is expected to answer the questions " why " and " how " in a case. Through the study of this, researchers are expected to able to dig up information from various sources, analyze and interpret it to reveal the terms of the fundamental of a case .

\section{Results And Discussion}

\subsection{The Role of Local Wisdom in Disaster Risk Reduction}

Mount Slamet, which has a height of 3,428 meters, is not as explosive as other mountains, such as Galunggung, Merapi, or Kelud. Two centuries of the history of the eruption of Mount Slamet, not one of them claimed a death (kompas.com, 2014). However, it should be remembered that there are quite a lot of people living in the disaster-prone area (KRB) of Mount Slamet. Based on data from the Regional Disaster Management Agency (BPBD) of Central Java Province, it is known that the number of populations living in disaster-prone areas (KRB) is quite large, amounting to 174,644 people (BPBD Central Java, 2018). The large population in the disaster-prone area (KRB) of Mount Slamet has the potential to cause significant casualties if there is no disaster risk reduction effort.

Table 1. Population in Disaster Prone Areas (KRB)

\begin{tabular}{cccccc}
\hline No. & districts & $\begin{array}{c}\text { Number of } \\
\text { districts affected }\end{array}$ & Districts & $\begin{array}{c}\text { Number of } \\
\text { Villages affected }\end{array}$ & $\begin{array}{c}\text { Total Population } \\
\text { Affected }\end{array}$ \\
\hline 1 & Pemalang & 1 & Pulosari & 7 & 34,228 inhabitants \\
2 & Purbalingga & 4 & $\begin{array}{c}\text { Mrebet, Karangreja, } \\
\text { Kutasari, Bojongsari }\end{array}$ & 11 & 65,185 inhabitants \\
3 & Banyumas & 3 & $\begin{array}{c}\text { Baturraden, Sumbang, } \\
\text { Kedungbanteng }\end{array}$ & 14 & 39,788 inhabitants \\
4 & Tegal & 1 & Bojong & 3 & 14,119 inhabitants \\
5 & Brebes & 2 & Sirampog, Paguyangan & 4 & 21,324 inhabitants \\
\multicolumn{2}{c}{ Total number } & 11 & & 34 & 174,644 \\
inhabitants
\end{tabular}

Source: Central Java Province BPBD, 2018

The large population in the disaster-prone area (KRB) of Mount Slamet actually reminds us that disaster management cannot be done alone by the government. Community and even private involvement is needed because disaster management is not only the responsibility of the government. Such understanding is actually in line with the conception of collaborative public leadership (Agranoff and McGuire 2003: 35-36) which involves various stakeholders involved in carrying out their respective interests in achieving common goals.

Respect for local wisdom has actually started with holding various Slamet mountain cultural festivals. One of them is the wong gunung festival which is a tribute to local wisdom in the form of tasyakuran harvesting crops, carnivals, exhibitions, and mountain rehearsals . The event, which is usually held every August, is a vehicle for the promotion of local culture and natural tourism potential which is needed by the people around Mount Slamet. In addition, the formation of Mount Slamet lover communities is also a breakthrough to revive local 
wisdom. As stated by the Chairman of the Organizing Festival Wong Mount Deni Suseno that the festival wong mountain (FWG) is a culinary and cultural preservation media local to the District tourist attraction Pulosari Pemalang.

In fact, harmony between actors is not automatically created even though the Wong gunung festival has been held. This is because one of the actors of local wisdom, namely the caretaker of Mount Slamet, was abandoned. The difference in views that often arise between the caretaker and the local government and the PVMBG (center of volcanology and geological disaster mitigation) is not pursued for a common ground. In the Islamic Kejawen belief system, what is meant by a caretaker is someone who is given or has the task of guarding places that are considered sacred or wingit . They are usually appointed by local rulers such as kings or village elders. His job is to keep the area entrusted to him free of trash, not damaged and remains natural. A key interpreter is the guardian of a culture or habit that has existed since time immemorial and dedicates not only his time but also his life to safeguarding a place that is considered sacred.

The Kejawen Islamic belief system has become an alternative belief system that is widely adhered to by the people around Mount Slamet. In this belief system it is believed that Mount Slamet will not erupt, unless it has arrived at the end of time. The community believes in the supernatural power that protects the sustainability and safety of the people and Mount Slamet. To become a caretaker at least there are several conditions that must be met. First, being able, diligently able to understand the legends that exist around the slopes of Mount Slamet, have a depth of knowledge and live around the slopes of Mount Slamet. Second, it is approved by the community through deliberation. Third, appointed and approved by the previous caretaker. However, the most important requirement is to have supernatural powers and be able to communicate directly with Mbah Jamur Dipa or Eyang Slamet by behaving in a troubled manner and meditating (Warsito, in Ariza, 2017). The existence of this caretaker is an important (non-bureaucratic) actor in disaster risk reduction efforts. The number of caretakers on Mount Slamet is quite a lot. There are at least 8 caretakers, each scattered on each of the Mount Slamet climbing routes.

Table 2. List of Mount Slamet Key Interpreters on each Hiking Route

\begin{tabular}{|c|c|c|c|}
\hline No. & Hiking trail name & Location & Mountain Locker \\
\hline 1 & $\begin{array}{c}\text { Bambangan Line In Kutabawa } \\
\text { Village, Kec. Karangreja Kab. } \\
\text { Purbalingga }\end{array}$ & $\begin{array}{l}\text { It is about } 5 \text { kilometers from the } \\
\text { summit }\end{array}$ & $\begin{array}{c}\text { Mbah Sumedi ( } 76 \\
\text { years) }\end{array}$ \\
\hline 2 & $\begin{array}{c}\text { Gambuhan Pulosari Pemalang } \\
\text { route }\end{array}$ & $\begin{array}{l}\text { It is 6-7 kilometers from the } \\
\text { summit / crater of Mount Slamet. }\end{array}$ & $\begin{array}{c}\text { Mbah Warjono (76 } \\
\text { Years) }\end{array}$ \\
\hline 3 & $\begin{array}{l}\text { The hiking trail of Dukuh } \\
\text { Liwung Guci Tegal Village }\end{array}$ & $\begin{array}{l}\text { It is about } 6 \text { kilometers from the } \\
\text { summit }\end{array}$ & $\begin{array}{c}\text { Mbah Karsad ( } 72 \\
\text { years) }\end{array}$ \\
\hline 4 & $\begin{array}{l}\text { Brebes hiking trail, Jurug } \\
\text { Pengantin Village }\end{array}$ & $\begin{array}{c}\text { About } 6 \text { Kilometers From the Top } \\
\text { of Mount Slamet }\end{array}$ & $\begin{array}{l}\text { Mbah Rutiah (67 } \\
\text { Years) }\end{array}$ \\
\hline 5 & Shower Trail 7 (Baturraden) & $\begin{array}{c}\text { Is 5-10 Kilometers From The } \\
\text { Peak. }\end{array}$ & $\begin{array}{l}\text { Mbah Slamet Samsuri } \\
\text { (89th) }\end{array}$ \\
\hline 6 & $\begin{array}{l}\text { Jurangmangu village climbing } \\
\text { route, Pulosari Pemalang }\end{array}$ & $\begin{array}{c}\text { It is } 4-5 \text { kilometers from the top } \\
\text { of Mount Slamet }\end{array}$ & $\begin{array}{c}\text { Mbah Khusaeri (70 } \\
\text { years) }\end{array}$ \\
\hline 7 & $\begin{array}{l}\text { Hiking route of Gunungsari } \\
\text { Pulosari Village, Pemalang }\end{array}$ & $\begin{array}{c}\text { It is } 4-5 \text { kilometers from the top } \\
\text { of Mount Slamet }\end{array}$ & $\begin{array}{l}\text { Mbah Khusaeri ( } 70 \\
\text { years) }\end{array}$ \\
\hline 8 & $\begin{array}{l}\text { Dhipajaya Pulosari Pemalang } \\
\text { climbing route }\end{array}$ & $\begin{array}{l}\text { It is } 4-5 \text { kilometers from the top } \\
\text { of the mountain }\end{array}$ & $\begin{array}{c}\text { Mbah Warsito ( } 77 \\
\text { years) }\end{array}$ \\
\hline
\end{tabular}


The existence of a caretaker with the Islamic Kejawen belief system is a representation of local wisdom which has become the "distinctive color" of almost all mountain caretakers throughout Indonesia, including Mount Slamet. This situation is also a representation of the belief system prevailing in society, especially those inhabiting the Mount Slamet area. In the Kejawen belief system, the caretaker is considered a representative / mediator in communication with the unseen world who cares for and preserves the mountain. Seeing the important role of this caretaker, the government cannot underestimate its existence, because it is part of the social reality that cannot be separated from efforts to reduce the risk of the Mount Slamet disaster.

Javanese kebatinan society has the view that Mount Slamet is the pulak navel (navel) of Java Island. Therefore, there are those who attribute the increase in mountain activities to the state of the country, especially in relation to the political heat. Mount Slamet is believed to be the residence of the Javanese ancestors, namely mbah Renti, Atasangin, Tapakangin, Semput and Brantayudha. The five are believed to be symbols of the five elements of life such as water, fire, wind, earth, and wood. So to maintain the relationship between humans and mountains, the caretakers of Mount Slamet always carry out their own rituals. Especially when Mount Slamet shows its activity.

Mount Slamet key interpreter who comes from the Village Clekatakan Pemalang, namely Mbah Khusaeri (83 years) said: "Mount Slamet Niku is still trying to get rid of Saged. Calm down mawon, sir. It's cute, maybe it's just falling. Lha progressing Niku, Terose Niku..terose Niku is still sinking, the end times are growing. Seeing the subsidence immediately after the kidul, I can't stop it, even if I don't want to do it. I need some mboten. Angger Kula is still trying to get rid of my grief, sir, wong tiyang even sami pejah ... Mboten saged. God willing, Slamet. Kados niku mawon. Sing, take care of Niku, Mbah Sulaiman, Mbah Puger, Kalih, the source of Kanoman. Niku sing the oldest tigo. Wonten wujude. Angger sumerep wujude mangke tiyange mboten saged wangsul. Kuburane pesareane is still wonten. Tapet, nika. Lha Niku Sing Ngajenge Mbah source, Pak Niku Segara Wedhi next to 60 hectares, terose tiyang old, Lha Niku Bengkalaie, I want to go back to my kenging with wong medal bramane. God willing, donga let mawon part of Central Java mriki, God willing, slamet. Angger Niku is really happy, sir. In fact, Niki, pack shoulders, stripped by the people, fled ... God willing, I wanted to stay displaced. Mangke angger fall still late. Clekatakan ... Semarang is finished. Niku terose tiyang elderly. (source: interview with Mbah Khusaeri, Clekatakan, 2020)

As a caretaker, Mbah Khusaeri believes that Mount Slamet will not erupt. There are unseen figures (mbah Sulaiman, mbah Puger and mbah Sumber Kanoman) who protect the mountain. Mountain activities (such as rumbling voices) are needed. People do not need to evacuate as ordered by the village government, because by praying and praying for one another, Mount Slamet will remain safe. It can be understood that disaster risk reduction efforts are very heavy due to the high diversity of actors and the complexity of the problems faced. The government does not want to take the risk of fully confirming the statement of the caretaker, not only because of the unscientific conclusions of the caretakers but also the lives of the people living around the disaster-prone areas of Mount Slamet. Uniquely, on the other hand, people actually trust the caretaker because of the belief system they adhere to.

Sigit Sanjaya (24 years), a youth leader in the Wong Gunung community in Gambuhan Village, Pemalang said: "We follow Mbah Khusaeri, because in fact Mount Slamet has never harmed him, even though we are afraid because of the rumble and the earthquake in 2019" (source: interview, 2019). On another occasion, Sugondo (45) the Village Head of Jurangmangu Pemalang also said: " Actually, we know that the Bupati was worried about the developments that occurred during the 2015 eruption. He was back and forth to the monitoring 
post and getting ready to order an evacuation." However, we are sure that Mount Slamet will not erupt. And in reality it didn't erupt. (source: interview, 2019)

It is realized that local wisdom in reducing Mount Slamet disaster risk still has a place in the community. However, it is unfortunate that there has been no compromise between the local wisdom of key gurus and the government's scientific approach in disaster risk reduction.

\subsection{Inhibiting Factors for the Role of Local Wisdom}

This study identifies at least 2 factors inhibiting the role of local wisdom in risk reduction. First, the problem of networking. Second, is the regulatory aspect. The seriousness of local governments as key actors in disaster risk reduction is "read" by the low space for local wisdom in disaster risk reduction. This means that it is no longer limited to the lack of regulations that provide space for public participation, but also the lack of respect for local wisdom. Governance networking is an attempt to maintain all network resources in good condition. In this aspect, the government and other actors still underestimate the position of key jurors. In de facto, the community still really trusts and respects the role of caretakers. As for the regulatory aspect of Law Number 24 of 2007 concerning Disaster Management, it has not yet given firm recognition to local wisdom which is manifested by the existence of a caretaker. This resulted in the emergence of conflict is $\mathrm{k}$ between jurukunci with local governments and other actors during the evacuation of residents from the vicinity of Mount Slamet.

\section{Conclusion}

The role of local wisdom in reducing the risk of Mount Slamet disaster is very important. Its presence complements the synergy of government, society and the private sector in disaster management. However, the government's lack of seriousness in making the caretaker of the mountain as a partner is actually an obstacle to the existence of the role of local wisdom. On another aspect, the presence of key jurors as actors of local wisdom also requires recognition in the law. For this reason, this study recommends: 1). It is necessary to open the doors of dialogue / communication between the government and local wisdom actors. 2) The need to review Law Number 24 of 2007 concerning Disaster Management in order to provide sufficient space for the work of local wisdom in disaster risk reduction.

\section{Reference}

[1] Agranoff, Robert. 2007. Managing Within Networks: Adding Value to Public Organizations . Georgetown University Press. Washington DC

[2] Ana Campos G., Niels Holm-Nielsen, Carolina Díaz G., Diana M. Rubiano V., Carlos R. Costa P., Fernando Ramírez C. and Eric Dickson. 2011. Analysis of Disaster Risk Management: A Contribution to the Creation of Public Policies . The World Bank Columbia and GFDRR (Global Facility for Disaster Reduction and Recovery

[3] Carlsson, Lars. 1996. Policy Networks as Collective Action . Workhsop in Political Theory and Policy Analysis, Indiana University USA

[4] Creswell. John. W. 2009. Qualitative Research and Research Design: Choosing among five approaches (3rd edition ) Student Library. Yogyakarta 
[5] Creswell. John. W. 2009. Research Design (Third Edition): Qualitative, Quantitative and Mixed Methods Approach . University of Nebraska, Lincoln. Sage

[6] Denzin, Norman K. 1970. The research act: A theoretical introduction to sociological methods. Aldine Publishing Company. Chicago

[7] Frank, Flo \& Anne Smith. The Partnership Handbook . Minister of Public and Government Services, Canada, 2000.

[8] Gerlach, Martin, Tiago P. Peixito and Eduardo G. Altmann, A Network Approach to Topic Models, Department of Chemical and Biological Engineering, Northwestern University, Evanston, IL 60208, USA, 2000

[9] Keban, Yeremias. T. 2004. Six strategic dimensions of Public Administration: Concepts, theories, and Issues. Gava Media Publishers. Yogyakarta

[10] Kusumasari, Bevaola. 2014. Disaster Management and Local Government Capabilities . Gava Media Publishers. Yogyakarta

[11] Kurtz, Thomas S. Intergovernmental Cooperation Handbook. Governor's Center for Local Government Services . Pennsylvania, 2002. 